\title{
Optimization Design on Recycle of Slurry Discharged from Lime Softening System
}

\author{
Ye Ding ${ }^{1, \mathrm{a}}$, Zhao $\mathrm{Li}^{1, \mathrm{~b}}$, Rui Rui ${ }^{1, \mathrm{c}}$ \\ ${ }^{1}$ Henan Electric Power Survey and Design Institute, Zhengzhou 450007, China \\ a dingye-heny@powerchina.cn, b ruirui-heny@powerchina.cn c ruirui-1005@163.com
}

Keywords: Lime softening treatment system; Slurry; Desulfurizer

\begin{abstract}
Lime softening \& side-stream lime softening method is used for circulating water treatment system in a certain Coal-fired power plant project of Henan Province. Main components of sludge discharged from lime softening system are $\mathrm{CaCO}_{3}$ and $\mathrm{Mg}(\mathrm{OH})_{2}$. This study analyzed the composition and discharge amount of sludge, as well as the influence of desulfurizer on desulfurization system and its benefits. The slurry of lime softening treatment could be used in desulfurization system, and would make better economic and environmental benefits.
\end{abstract}

\section{Introduction}

Two 600MW supercritical condensing units are constructed in a certain coal-fired power plant in Henan Province, and the desulfurization system is the wet limestone-gypsum FGD method due to its mature technology, high efficiency and reliable operation ${ }^{[1]}$. The main absorber is limestone, of which the content of $\mathrm{CaCO}_{3}$ is about $90 \%$.

Lime softening \& side-stream lime softening method is used for circulating water treatment system. The slaked lime is added to water and reacts with the carbonate hardness, which generates the precipitation of $\mathrm{CaCO}_{3}$ and $\mathrm{Mg}(\mathrm{OH})_{2}$ and reduces the hardness and alkalinity of water. Lime treatment system has the advantage of low operation cost, little environment pollution, and there is no great quantity of soluble salt in the water and no discharged wastewater. The contents of materials in the water such as organic matter, silicide, and iron could be reduced after lime softening treatment ${ }^{[2]}$.

The lime advanced treatment method is used for municipal reclaimed water in the plant, and the slurry produced in lime treatment process could be transported to ash field for landfill treatment by vehicle after dehydration. However, the operation of ash field could be affected by hundreds of tons of sludge cakes transporting out and stacking in ash field every day. Besides, the original design of ash field neglects the treatment of sludge cakes. Also, the sludge cakes are required to be dealt with properly by environmental protection department to avoid environmental pollution. Limestone is the main component of desulfurizer in wet limestone-gypsum flue gas desulfurization (FGD) system. Considering the high cost of existing operation mode, the requirements of environmental protection department and the component of desulfurizer, the slurry, of which the main component is $\mathrm{CaCO}_{3}$ and produced in lime treatment process of municipal reclaimed water, could be sent directly to the desulfurization slurry tank and used as desulfurization material. The methods above could reduce operation cost and environmental pollution.

\section{Composition Analysis}

During the reacting process of lime treatment system, the main equations of lime treatment are listed as follow ${ }^{[3-5]}$.

$$
\begin{gathered}
\mathrm{CO}_{2}+\mathrm{Ca}(\mathrm{OH})_{2} \rightarrow \mathrm{CaCO}_{3} \downarrow+\mathrm{H}_{2} \mathrm{O} \\
\mathrm{Ca}\left(\mathrm{HCO}_{3}\right)_{2}+\mathrm{Ca}(\mathrm{OH})_{2} \rightarrow 2 \mathrm{CaCO}_{3} \downarrow+2 \mathrm{H}_{2} \mathrm{O} \\
\mathrm{Mg}\left(\mathrm{HCO}_{3}\right)_{2}+\mathrm{Ca}(\mathrm{OH})_{2} \rightarrow 2 \mathrm{CaCO}_{3} \downarrow+\mathrm{Mg}(\mathrm{OH})_{2} \downarrow+2 \mathrm{H}_{2} \mathrm{O} \\
2 \mathrm{NaHCO}_{3}+\mathrm{Ca}(\mathrm{OH})_{2} \rightarrow \mathrm{Na}_{2} \mathrm{CO}_{3} \downarrow+\mathrm{CaCO}_{3} \downarrow+2 \mathrm{H}_{2} \mathrm{O} \\
\mathrm{Fe}^{3+}+3 \mathrm{OH}^{-} \rightarrow \mathrm{Fe}(\mathrm{OH})_{3} \downarrow
\end{gathered}
$$

The equations above show that the main products of lime treatment system of reclaimed water 
are $\mathrm{CaCO}_{3}$ and $\mathrm{Mg}(\mathrm{OH})_{2}{ }^{[6]}$. Due to the water quality of this project is negative hardness water, all the alkalinity would be transformed to precipitation of $\mathrm{CaCO}_{3}$ and $\mathrm{Mg}(\mathrm{OH})_{2}$. The composition and content, which are shown in Table 1, are calculated according to the summer water quantity during lime softening process. The water quantity includes supplementary water of $2500 \mathrm{t} / \mathrm{h}$ and side flow of $1000 \mathrm{t} / \mathrm{h}$.

Table 1 Composition and Content Analysis of Slurry

\begin{tabular}{ccccccc}
\hline \multicolumn{1}{c}{ Item } & $\mathrm{CaCO}_{3}$ & $\mathrm{Mg}(\mathrm{OH})_{2}$ & $\mathrm{Fe}(\mathrm{OH})_{3}$ & $\begin{array}{c}\mathrm{SS} \text { and other } \\
\ldots .\end{array}$ & Total \\
\hline $\begin{array}{c}\text { Sediment concentration } \\
(\mathrm{mg} / \mathrm{L})\end{array}$ & $\begin{array}{c}\text { Make-up } \\
\text { water system }\end{array}$ & 867 & 47 & 10.7 & 25 & 950 \\
\cline { 2 - 7 } & $\begin{array}{c}\text { Side stream } \\
\text { system }\end{array}$ & 280 & & 10.7 & 90 & 380 \\
\hline $\begin{array}{c}\text { Make-up } \\
\text { Absolutely dry mud } \\
\text { quantity (kg/h) }\end{array}$ & $\begin{array}{c}\text { Side stream } \\
\text { system }\end{array}$ & 2167.5 & 117.5 & 26.8 & 62.5 & 2375 \\
\hline Total Absolutely dry mud (kg/h) & 2447.5 & 117.5 & 37.5 & 152.5 & 2755 \\
\hline Each component content (\%) & 88.8 & 4.3 & 1.4 & 5.5 & 100 \\
\hline Slurry(10\% water content) (t/h) & & & 27.5 & & \\
\hline
\end{tabular}

The table above shows the lime softening of circulating water system produces $10 \%$ slurry of $27.5 \mathrm{t} / \mathrm{h}$ and absolute dry mud of $2.75 \mathrm{t} / \mathrm{h}$. The composition of $\mathrm{CaCO}_{3}$ in absolute dry mud is $88.8 \%$, which is slightly lower than limestone used in desulfurization system. The slurry generated in lime softening process is added evenly with a certain proportion to slurry tank of desulfurization system. According to design coal, the limestone consumption for desulphurization of two units is about $25.3 \mathrm{t} / \mathrm{h}$. The purity of desulfurizer changes from $90 \%$ to $89.9 \%$ after mixing with the slurry, so the proportion of slurry is very small and the influence on the purity of desulfurization sorbent is extremely slight ${ }^{[7]}$. Therefore, the slurry produced in lime softening system could be used as absorbent of desulfurization system.

\section{Optimization of Lime Slurry Treatment System}

To make lime slurry be used as desulfurization material, slurry treatment process of reclaimed water advanced treatment system should be transformed. The slurry of concentrator shall be transferred to desulphurization limestone slurry tank regularly by piping. The main process of lime treatment and slurry recycling system after transformation are shown in Fig. 1.

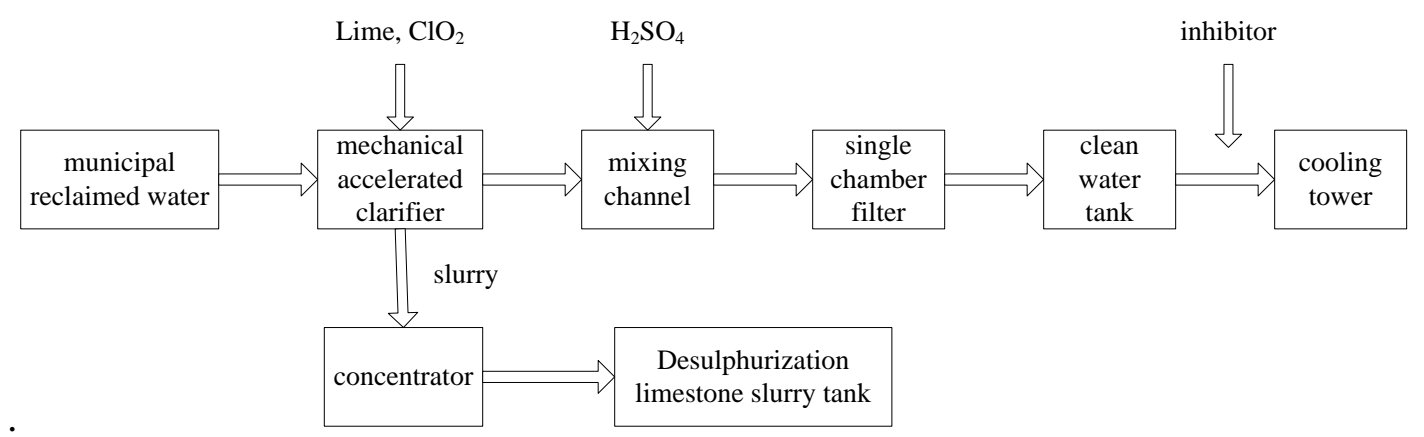

Fig.1 Main Process of Lime Softening and Slurry Recycling System

After transformation of the system, the dehydrator shuts down, but the piping system is remained. Normally the slurry is conveyed by the slurry pump to limestone slurry tank as desulfurizer. During the startup of unit and maintenance of desulfurization system, the slurry shall be conveyed to dehydrator, and sludge cake shall be transported to ashyard. 


\section{Effects of Slurry of Lime Treatment System on Desulfurization Efficiency}

\subsection{Effect of Slurry on the Quality of Gypsum}

A certain amount of impurities are contained in the slurry of lime treatment system, and it will enter into the absorption tower through desulfurization system. At last, some impurities would be discharged with desulfurization wastewater, and others would be excluded in form of gypsum from absorption tower. Assume all the impurities in slurry entered into the gypsum, the gypsum production of desulfurization system should be calculated as about $45.54 \mathrm{t} / \mathrm{h}$ (at purity of $90 \%$, water content of $10 \%$ ) according to the check coal, due to the low production of slurry (convert into absolute dry mud of $2.75 \mathrm{t} / \mathrm{h}$ and impurity content is $11 \%$ ). The maximum content of impurities in gypsum causing by slurry shall be: $2.75 \times 0.11 /(45.54 \times 90 \%)=0.74 \%$. Thus, when the slurry from lime treatment system was added to desulfurization system, the content of impurities in gypsum would increase no more than $1 \%$. So the transformation of desulfurization system has little influence on the quality of gypsum.

\subsection{Effect of Slurry on Desulfurization Efficiency}

The smaller the particle size of limestone is, the greater the area of specific surface is. And the greater the contact area between limestone and slurry is, the more conducive to the desulfurization reaction. Therefore desulfurization efficiency would be not reduced but be improved to some extent when the slurry from lime treatment system was added to desulfurization system ${ }^{[8]}$. After pilot test, the desulfurization efficiency and the quality of gypsum showed no obvious degradation comparing the desulfurization efficiency under different load, whereas the desulfurization efficiency increased by $0.5 \% \sim 2 \%$ (Table 2 ) after adding the slurry.

Table 2 Influence of Slurry on Desulfurization Efficiency

\begin{tabular}{ccccc}
\hline Item & Unit load & $\begin{array}{c}\text { Absorption } \\
\text { tower } \mathrm{pH}\end{array}$ & $\begin{array}{c}\text { Original } \\
\mathrm{SO}_{2} \text { concentration }\end{array}$ & $\begin{array}{c}\text { Desulfurization } \\
\text { efficiency }\end{array}$ \\
\hline Unit & $\mathrm{MW}$ & $/$ & $\mathrm{mg} / \mathrm{m}^{3}$ & $\%$ \\
\#1boiler & 355 & 5.5 & 2240 & 96.2 \\
$\begin{array}{c}\text { \#2boiler (adding } \\
\text { slurry) }\end{array}$ & 368 & 5.53 & 2275 & 97.1 \\
$\begin{array}{c}\text { \#1boiler } \\
\text { \#2boiler (adding } \\
\text { slurry) }\end{array}$ & 463 & 5.98 & 2780 & 95.9 \\
\hline
\end{tabular}

\subsection{Effect of Slurry on Gypsum Dehydration}

According to the situation of commissioning, polyacrylamide and polyferric sulfate added during the water treatment process had entered the reclaimed water slurry mostly. Polyacrylamide had strong flocculation and excellent adhesiveness and stability. It would greatly improved the viscosity of limestone slurry and formed slurry clannishness once entered in the absorption tower, which would worsen the slurry quality and cause serious negative influence on the desulfurization rate, gypsum crystallization and gypsum dehydration. Coagulant would also have degradation influence on desulfurization slurry, but a small amount of coagulant would not lead to obvious operation change of absorption tower.

Lime treatment of reclaimed water would form the large size of calcium carbonate, of which the settling velocity is not slow. The addition of coagulant aid and coagulant are used for further improvement of sedimentation rate. The slurry separation layer of accelerated clarifier would rise without coagulant aid. But adding a small amount of coagulant through adjustment would make sure the stability of separation layer and the water quality of accelerated clarifier. Even if the chance of sediment upturning of accelerated clarifier would increase, the filters after accelerated clarifier would make the final water quality meet the requirement. 
On the premise of guaranteeing the quality of circulating water, polyacrylamide and coagulant dosage shall be as less as possible during normal operation.

\section{Benefit of Recycling Slurry of Lime Treatment System}

Since the rate of recycling slurry, using as desulfurization material, was $2.75 \mathrm{t} / \mathrm{h}$ and its purity was $89 \%$ and annual utilization hours was 5500, the limestone consumption of desulfurization system could reduce about $14960 \mathrm{t} / \mathrm{h}$ annually(converting into the purity of $90 \%$ ). Considering the slurry volume decreased in the winter because of the reduction of supplementary water, limestone consumption could be saved of about 8,000t/h each year, namely 800,000 yuan/a according to the market price of 100 yuan/t. The power consumption of desulfurization slurry preparation system could save about 900,000 kilowatt-hours every year. The total economical value is about 3 million yuan/a, including the cost saving of reclaimed water slurry treatment and the chemicals.

At the same time, the slurry recycling technology had not only completely solved the pollution during transportation and storage of sludge, realizing the purpose of "using pollution to control pollution”, but also stopped power plant external discharging by replacing part of the limestone. In addition, the slurry recycling technology also improved the environmental health in dehydration area of lime treatment system, prolonged the service life of the ash field, and achieved the purpose of using waste to treat waste and energy conservation and emissions reduction.

\section{Conclusions}

It is feasible that the slurry of circulating water in lime softening system is used as material of limestone wet desulfurization system, which not only reduces the running and maintenance cost of the lime processing system, but also solves the problem of comprehensive utilization of waste sludge.

\section{Reference}

[1]Tian Bin. Approach to desulfurization efficiency and technical problems of wet desulfurization. J. ELECTRIC POWER ENVIRONMENTAL PROTECTION, 2008, 24(5): 35-36.

[2]Wei Huan. Case Study of the Secondary Drainage in Urban Sewage Treatment Plant Through Lime Treatment for Thermal Power Plant. J. PUBLIC COMMUNICATION OF SCIENCE \& TECHNOLOGY. 2010, (3): 90-91.

[3]Long Xiao, Shang Wenxia, Liu Kecheng, etc. Research on the Reuse Wastewater Treatment by Lime Process in Power Plant. J. INDUSTRIAL SAFETY AND ENVIRONMENTAL PROTECTION. 2010, 36(1): 17-19.

[4]Zhang Xinhe. Application of lime treatment in municipal wastewater reuse in power plants. J. ELECTRIC POWER. 2007, 40(2): 40-42.

[5]Li Peiyuan, Zhou Boqing. Water treatment and water quality control in power plant. M.Beijing: China Electric Power Press, 2012:1-696.

[6]Yuan Gang, Ma Yongliang, Wang Lidong. Study on the characteristics of flue gas desulfurization by magnesium oxide. J. CHINESE JOURNAL OF ENVIRONMENTAL ENGINEERING. 2010, 4(5): 1134-1135.

[7]Wu Wenjiang. Wet limestone \& gypsum desulphurization method: Flue gas desulfurization technology. M. Beijing: Water Resources and Electric Power Press, 2006.

[8]Yin Hongmei. The influence factors on desulfurization efficiency of wet limestone \& gypsum desulphurization process. J. China Science \& Technology Panorama Magazine. 2014, (10): 61-62. 